\title{
Application of the video-tutorial "Challenge for Referees" in sports training of young basketball referees for the game season
}

\author{
Sobko I.M. ${ }^{1}$, Chucha Y.I. ${ }^{2}$, Podmaryova I.A. ${ }^{3}$, Nagovitsyna O.P. ${ }^{3}$, Zhuravlova I.M. ${ }^{4}$ \\ ${ }^{1}$ H. S. Skovoroda Kharkiv National Pedagogical University \\ ${ }^{2}$ Kharkiv State Academy of Physical Culture \\ ${ }^{3}$ S. Kuznets Kharkiv National University of Economics \\ ${ }^{4}$ Municipal establishment "Kharkiv humanitarian-pedagogical academy" of the Kharkiv regional \\ council
}

\section{DOI: https://doi.org/10.34142/HSR.2021.07.01.04}

\section{How to Cite}

Sobko IM, Chucha YI, Podmaryova IA, Nagovitsyna OP, Zhuravlova IM. Application of the video-tutorial "Challenge for Referees" in sports training of young basketball referees for the game season. Health, Sport, Rehabilitation. 2021;7(1):42-53. https://doi.org/10.34142/HSR.2021.07.01.04

\begin{abstract}
Purpose : to develop and experimentally substantiate the use of the video manual "Challenge for Referees" in the sports training of young basketball referees for the playing season.

Material and methods: young basketball referees (30 people), category C, (18-20 years old) refereeing experience of one year took part in the experiment. The control and experimental groups of 15 people were randomly allocated. All participants agreed to participate in the experiment. The study was conducted from June to August 2020. At the beginning and at the end of the experiment, all study participants underwent complex physical testing (push-ups $30 \mathrm{~s}$, long jump from a place, jumping rope in 1 minute, running $3000 \mathrm{~m}$, lifting the trunk in sitting position for 1 min, pulling up on the bar, stretch of the upper-body forward from a sitting position, Romberg's test), functional (Rufier's test, Genchi's test, Stange's test), psychophysiological state testing using the" Psychodiagnostics "computer program. The indicators of the speed of a simple visual-motor reaction and the speed of a complex visual-motor choice reaction, mathematical and statistical methods were determined.

Results. A video manual "Challenge for Referees" has been developed and introduced into the training process, with the help of which it is possible to determine the level of complex preparedness of young basketball referees, their psychophysiological capabilities. This manual provides sets of exercises and examples of training sessions to improve the physical, technical and theoretical preparedness of referee of category $\mathrm{C}$ in preparation for the playing season.

Conclusions. It is shown that as a result of the experiment, the indicators of technical, physical and functional readiness of basketball referee of the experimental group significantly $(p<0.05)$ improved in comparison with the control group. As a result of the method of expert assessments, significant $(p<0.05)$ differences were revealed in the indicators of technical readiness of the experimental group in comparison with the control group.

Key words: basketball, refereeing, video tutorial, physical fitness, functionality
\end{abstract}




\title{
Анотація
}

Собко І.М., Чуча Ю.І., Подмарьова І.А., Наговіцина О.П., Журавльова І.М. Застосування відео-посібника "Challenge for referees» у спортивній підготовці молодих суддів з баскетболу до ігрового сезону

Мета: розробити та експериментально обгрунтувати застосування відео посібника «Challenge for Referees» у спортивній підготовці молодих суддів з баскетболу до ігрового сезону.

Матеріал і методи: в експерименті взяли участь молоді судді з баскетболу (30 чоловік), категорія С, (вік 18-20 років стаж суддівства один рік. Випадковим способом було виділено контрольну та експериментальну групи по 15 чоловік. Усі учасники дали згоду про участь у експерименті. Дослідження проводилось з червня по серпень 2020 року. На початку експерименту та після усі учасники дослідження пройшли комплексне тестування фізичної підготовленості (згинання розгинання рук в упорі лежачі за 30 с, стрибок у довжину з місця, стрибки зі скакалкою за 1 хвилину, крос 3000 м, піднімання тулуба в сід за 1 хв, підтягування на перекладині, Нахил тулуба вперед із положення сидячи, проба Ромберга), функціональних можливостей (проба Руф'є, проба Генчі, проба Штанге), тестування психофізіологічного стану за допомогою комп'ютерної програми "Психодіагностика". Були визначені показники швидкості простої зорово-моторної реакції та швидкості складної зорово-моторної реакції вибору, математико-статистичні методи.

Результати: Розроблено та впроваджено до тренувального процесу відео посібник «Challenge for Referees» за допомогою якого можна визначити рівень комплексної підготовленості молодих суддів з баскетболу, їх психофізіологічні можливості. В даному посібнику надано комплекси вправ та приклади тренувальних занять для удосконалення фізичної, технічної та теоретичної підготовленості суддів категорії С під час підготовки до ігрового сезону.

Висновки. Показано, що в результаті проведення експерименту достовірно $(p<0,05)$ поліпшились показники технічної, фізичної та функціональної підготовленості баскетбольних суддів експериментальної групи в порівнянні з контрольною групою. В результаті проведення методу експертних оцінок виявлені достовірні $(p<0,05)$ відмінності в показниках технічної підготовленості експериментальної групи в порівнянні з контрольною групою.

Ключові слова: баскетбол, суддівство, відео посібник, фізична підготовленість, функціональні можливості

\begin{abstract}
Аннотация
Собко И.Н., Чуча Ю.И., Подмарева И.А., Наговицина О.П., Журавлева И.Н. Применение видео-пособия "Challenge for referees» в спортивной подготовке молодых судей по баскетболу к игровому сезону.

Цель: разработать и экспериментально обосновать применение видео пособия "Challenge for Referees» в спортивной подготовке молодых судей по баскетболу к игровому сезону.

Материал и методы: в эксперименте приняли участие молодые судьи по баскетболу (30 человек), категория C, (возраст 18-20 лет) стаж судейства один год. Случайным образом было выделено контрольную и экспериментальную группы по 15 человек. Все участники согласились об участии в эксперименте. Исследование проводилось с июня по август 2020 года. В начале и в конце эксперимента все участники исследования прошли комплексное тестирование физической подготовленности (сгибание разгибание рук в упоре лежа за $30 \mathrm{c}$, прыжок в длину с места, прыжки со скакалкой за 1 минуту, кросс 3000 м, подъем туловища в сед за 1 мин, подтягивание на перекладине, наклон туловища вперед из положения сидя, проба Ромберга), функциональных возможностей (проба Руфье, проба Генчи, проба Штанге), тестирование психофизиологического состояния с помощью компьютерной программы "Психодиагностика". Были определены показатели скорости простой зрительно-моторной реакции и скорости сложной зрительно-моторной реакции выбора, математикостатистические методы.
\end{abstract}

Результаты. Разработано и внедрено в тренировочный процесс видео пособие «Challenge for Referees» с помощью которого можно определить уровень комплексной подготовленности молодых судей по баскетболу, их психофизиологические возможности. В данном пособии даны комплексы упражнений и примеры тренировочных занятий для совершенствования физической, технической и теоретической подготовленности судей категории С при подготовке к игровому сезону.

Выводы. Показано, что в результате проведения эксперимента достоверно $(p<0,05)$ улучшились показатели технической, физической и функциональной подготовленности баскетбольных судей экспериментальной группы по сравнению с контрольной группой. В результате проведения метода экспертных оценок выявлены достоверные $(p<0,05)$ различия в показателях технической подготовленности экспериментальной группы по сравнению с контрольной группой.

Ключевые слова: баскетбол, судейство, видео пособие, физическая подготовленность, функциональные возможности 


\section{Introduction}

Modern basketball requires good athletic training not only from the players, but also from the referees. Refereeing activity in basketball is characterized by a varied set and specific nature of working actions. The professional activity of an arbitrator requires special versatile preparedness [12]. Poor physical fitness affects the mechanics of the referees' movements on the court, the correct choice of place, affects the increase in the number of errors. According to experts, special physical training is necessary, regardless of the age and experience of the referees [3-4]. Physical training plays a leading role in the formation of a referees motor abilities and is directly dependent on the development of endurance, speed-strength qualities, speed. A distinctive feature of the referees' quickness manifestation is a quick change of game situations and the presence of many different factors (psychological tension, fatigue, etc.) The speed of the starting acceleration and distance speed is the foundation of speed in basketball [5].

Also, refereeing is an intellectual activity of the referee, associated with the ability to control the process of the game. The nature and results of most basketball competitions depend on the quality of the refereeing. The more the referee's experience as a referee, the less unexpected situations arise for him. The referees must be resourceful, quick-witted, quickly navigate difficult situations. Intellectual qualities reinforce the didactic skills of the referees and help him find the right decisions in his work. Intellectual qualities determine the effectiveness of work, I help to look for new ways to solve emerging problems in the organization of competitions. These qualities include: clarity and consistency of thinking, criticality, imagination, ingenuity, wit [6-7].

A special role in the activity of a referees is played by the efficiency of thinking, which characterizes the ability to quickly find the optimal solution for emerging controversial problems. The referee must know and understand the rules of the game well, accurately record the mistakes of the players. The referee in basketball must be mobile and choose the right place on the court in order to better see the playing moment. The necessary quality of the referees is the speed of reaction and the correct assessment of this situation on the court, which allows timely recording of violations of the rules [89].

Therefore, it is necessary to search for new forms, methods and means of training young basketball referees. Currently, seminars on the training of basketball referees are regularly held.
There are many online resources for training referee [10].

However, at the moment there are no video manuals in Ukrainian with a description and explanation of tests with physical, functional, technical and psychophysiological readiness of referee to determine the level of complex readiness of young basketball referees.

In this regard, the purpose of our research was the development and experimentally substantiate the use of the video manual "Challenge for Referees" in the sports training of young basketball referees for the playing season.

\section{Matherials and methods}

\section{Participants}

The study involved basketball referees category $\mathrm{C}$ in the amount of 30 men from different cities of Ukraine (Kharkov, Nikolaev, IvanoFrankovsk, Kiev, Zaporozhye). Participants were recruited by looking for referees who refering at least three times a week for 1 game per day and were able to complete the full experiment. Participants were eligible for inclusion if they: (1) have category C; (2) have 1 year refereeing experience; (3) were aged 1820 years old.

The control and experimental groups of 15 people were randomly allocated. All participants agreed to participate in the experiment. An independent statistician randomized the athletes in parallel to a control group and an intervention group using a random distribution method using an online random number generator program.

Table 1 presents the anthropological characteristics of the participants. No significant difference was found between the experimental groups and the control group.

\section{Procedure}

Determination of the physical preparedness level.

Control tests of physical fitness were carried out by the estimation of level of development of certain motor qualities. push-ups $30 \mathrm{~s}$, number of times; jumping rope in 1 minute, number of times; cross $3000 \mathrm{~m}$, min; lifting the trunk in sitting position for $1 \mathrm{~min}$, number of times; pulling up on the bar, number of times; stretch of the upper-body forward from a sitting position, (sm), long jump from a place (sm); Romberg's test, s. 
The detailed information of the participants (men) $(\mathrm{N}=30)$.

\begin{tabular}{|c|c|c|c|}
\hline $\begin{array}{l}\text { Anthropological } \\
\text { Information }\end{array}$ & $\begin{array}{l}\text { Experimental group } \\
\qquad(\mathrm{N}=15) \\
\text { Mean } \pm \mathrm{SD}\end{array}$ & $\begin{array}{l}\text { Control group } \\
\qquad(\mathrm{N}=15) \\
\text { Mean } \pm \mathrm{SD}\end{array}$ & $p$ \\
\hline Age, years & $19.06 \pm 0.88$ & $18.8 \pm 0.83$ & 0.52 \\
\hline Height, cm & $176.6 \pm 4.56$ & $175.6 \pm 8.33$ & 0.42 \\
\hline Weight, kg & $77.73 \pm 5.84$ & $76.2 \pm 4.76$ & 0.43 \\
\hline
\end{tabular}

Abbreviations: SD, standard deviation

\section{Determining the level of functionality}

The Shtange test (holding the breath while inhaling) was carried out in a sitting position: the athlete takes a deep breath and exhale, then inhale again (approximately $80 \%$ of the maximum), closes his mouth and pinches his nose with his fingers, holds his breath (the stopwatch starts at the end of inhalation).

Gench test. The pulse is measured in 30 seconds in a standing position, then the breath is held on a full exhalation, after three breaths in 3/4 depth. During detention, you must use a nose clip. Time is recorded by a stopwatch in seconds. Then you need to measure the pulse for 30 seconds immediately after the restoration of breathing. If the delay is less than 34 seconds, the result is considered unsatisfactory. A result within 35-39 seconds indicates a satisfactory indicator, and a time of more than 40 seconds is a good result.

Rufier's test. In a subject lying on his back for 5 minutes, the number of pulsations is determined for $15 \mathrm{~s}(\mathrm{P} 1)$ then for $45 \mathrm{~s}$. the tried and tested one performs 30 squats. After the end of loading, the tested person lies down, and the number of pulsations is counted again for the first $15 \mathrm{~s}(\mathrm{P} 2)$, and then - for the last 15 from the first minute of the recovery period (P3). The performance of the heart is assessed according to the formula:

Rufier's index $=(4 *(\mathrm{P} 1+\mathrm{P} 2+\mathrm{P} 3)-200) /$

10 The results are assessed by the value of the index from 0 to 15. Less than 3 - good performance 3-6 average; 7-9 - satisfactory; 10-14 - bad (moderate heart failure) 15 and above (severe heart failure)

To determine the psycho-physiological state of athletes, psycho-physiological indicators were recorded using a computer program. "Psychodiagnostics"[11]. The following parameters were fixed:

- a set of indicators for the rate of a simple visual-motor reaction (mean of 30 attempts (ms), standard deviation (ms), number of errors); duration of exposure (signal) - $900 \mathrm{~ms}$;
- complex indicators of a complex visualmotor reaction of selecting two of the three elements (average of 30 attempts (ms), standard deviation (ms), number of errors); duration of exposure (signal) $-900 \mathrm{~ms}(\mathrm{~s})$.

\section{The method of expert assessments}

An expert committee of three referee of the FIBA category assessed the correctness of the double mechanics of refereeing and gesticulation of the referee during control games on a five-point scale.

(5 - technical actions were performed without errors, 4 - technical actions were performed with two or three errors (incorrectly selected position referee on the site; errors in showing gestures), 3 - technical actions were performed with gross errors (incorrect movement around the site; obstacle to the actions of athletes; showing gestures does not correspond to the rules of the competition), 2 - failure to perform technical actions).

\section{Statistical analis}

The digital material obtained during the research was processed using traditional methods of mathematical statistics. For each indicator, the arithmetic mean value of $\mathrm{X}$, the standard deviation $\mathrm{S}$ (standard deviation), the assessment of the significance of differences between the parameters of the initial and final results, as well as between the control and experimental groups by the Student t-test with the corresponding significance level $(p)$ were determined. Mathematical data processing was carried out with the help of Microsoft Excel Analysis Data Analysis Software, SPSS. Differences were considered significant at a significance level of $p$ $<0.05$.

The study was conducted from June to August 2020. At the beginning of the experiment and after, all participants in the study underwent comprehensive testing of physical, functional and theoretical readiness. During the experiment, the experimental group was asked to use the developed 
video manual to prepare for the basketball game season 2020-2021. Also, before and after the experiment, the method of expert assessments was carried out for all participants in the study to test the technical preparedness of referee.

The control group prepared independently according to the traditional training system.

The main components of the training of referee are theoretical and practical parts, which are interrelated. The tasks of theoretical training are knowledge of the official rules, their interpretations, and the mechanics of refereeing. The effectiveness of practical training directly depends on the practice of refereeing basketball games, that is, a clear application of theoretical knowledge.

The video manual "Challenge for Referees" (Fig. 1) contains sections with which you can determine the level of physical, functional and technical readiness of young basketball referees, their psychophysiological capabilities, the last section contains practical recommendations and examples of training sessions to prepare for the playing season.
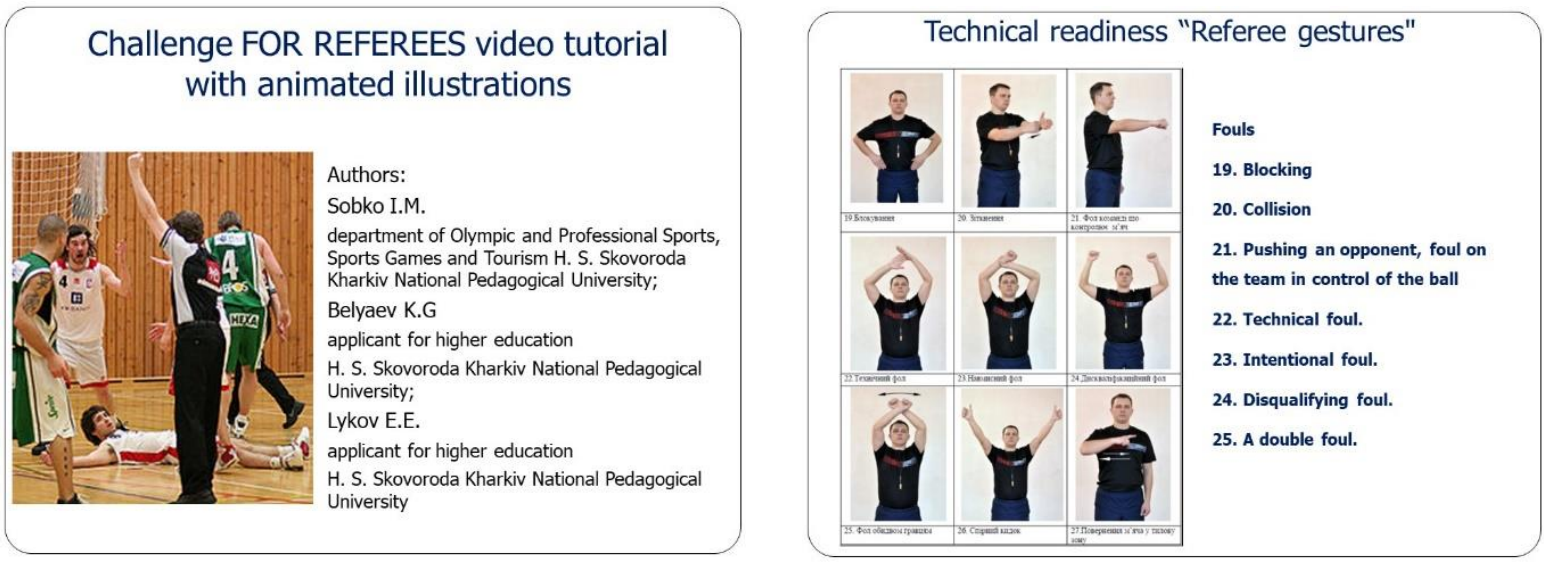

Fig. 1. Illustrated video tutorial "Challenge for Referees"

The video tutorial "Challenge for Referees" has the following sections:

\section{referee}

Section 1 Testing the physical fitness of

This section contains a detailed description, photos and videos of all tests, as well as a grading scale.

The normal distribution law will be used as the basis for constructing the assessment scales. The average value in the sample is to answer with an average estimate ("average results") of a value that is 1 standard deviation greater than the average - a good estimate ("maximum-sufficient results"); 2 standard deviation is an excellent mark ("maximum results"); accordingly, a value that is less than the average by 1 standard deviation is a satisfactory mark ("minimum required results"); by 2 standard deviation - a low score ("acceptable results") (rable 2).

Model characteristics of referee in basketball category C $(n=40)$

\begin{tabular}{cccccc}
\hline \multirow{2}{*}{ Name of metrics } & \multicolumn{5}{c}{ Rating scale } \\
\cline { 2 - 6 } & admissible & min necessary & averaged & $\begin{array}{c}\text { max. } \\
\text { sufficient }\end{array}$ & maximum \\
\hline Push-ups 30 s, number of times & 20 & 23 & 26 & 30 & 32 \\
\hline $\begin{array}{c}\text { Lifting the torso to sit for 1 } \\
\text { minute, number of times }\end{array}$ & 35 & 38 & 42 & 47 & 55 \\
\hline
\end{tabular}

\section{Section 2. Testing of special physical fitness of referee}

Videos of tests are presented:

1. The "Metronome" test is the main test for assessing the level of physical fitness of basketball referee, proposed by the International Basketball Federation (FIBA) to all national federations. Regulatory requirements: for men, it is necessary to run a distance of 1720 meters in 10 minutes, a distance of 20 meters by shuttle running, touching the line limiting the distance, at a sound signal. The 
number of errors during test execution is recorded.

2. The shuttle run test was proposed by FB Dmitriev "[12], it is necessary to run the proposed shuttle distance three times. The rest interval between the first and second attempts is 30 seconds, between the second and third attempts is 45 seconds. The best result was recorded (Fig. 2).

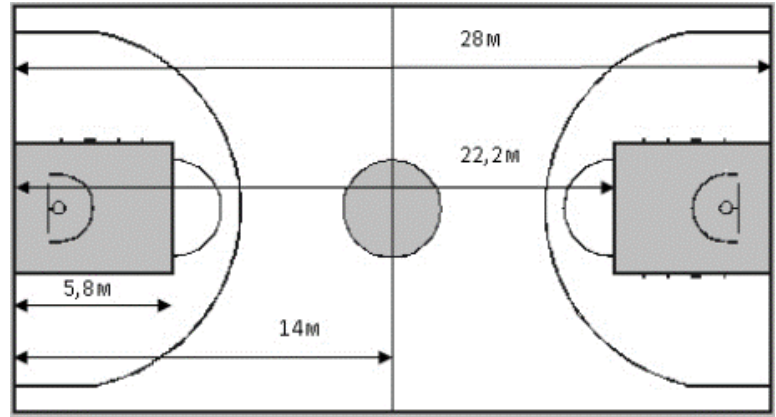

Fig. 2. The illustration to the Shuttle Run Test

Moveable game for the development of endurance "Cross in a circle"

Inventory: racks. Course of the game: 4 racks are placed on the court so that players, running around them, move along a rectangle. The distance between the posts is $15-20 \mathrm{~m}$ (long sides of the rectangle) and $8-10 \mathrm{~m}$ (short sides). The game involves two teams of 4 children, which are evenly spaced around the perimeter of the rectangle one after another. At the command of the players begin to run counterclockwise, bending around the rack. The task of each is to tag the player of another team. The signal for the end of the game is given when 3 people from the team are tagged.

\section{Section 3. Testing functionality}

The description of the tests "Gencha's test", "Shtange's test", "Rufier's test" is presented.

\section{state \\ Section 4. Testing the psychophysiological}

To determine the psychophysiological state in the video manual, a computer program
"Psychodiagnostics" is installed with which you can determine the speed of a simple and complex reaction to a light stimulus and establish the level of functional mobility and the strength of the nervous processes of referee.

\section{Section 5. Testing of theoretical readiness}

The section for testing theoretical readiness has tests with video files, after viewing which the referees must choose the correct answer.

Examples of foul tests that are played using short video files:

Test 1 (Fig. 3). Who is fouled and why?

A) Unsportsmanlike foul against player \# 0 (purple kit) and unsportsmanlike foul against player \# 9 (yellow kit)

B) Unsportsmanlike foul against player \# 0 (purple kit) and a disqualifying foul against player \# 9 (yellow kit)

C) Foul (normal) against player \# 9 in yellow uniform

D) a disqualifying foul against player \# 0 (purple kit) and a disqualifying foul against player \# 9 (yellow kit)

Answer: B

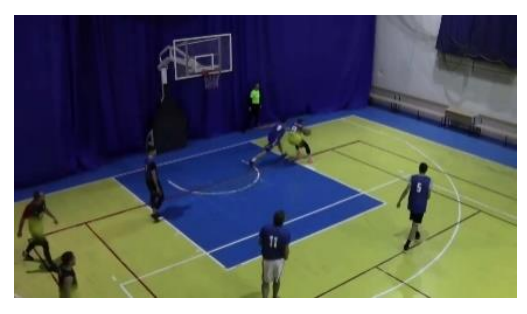

1

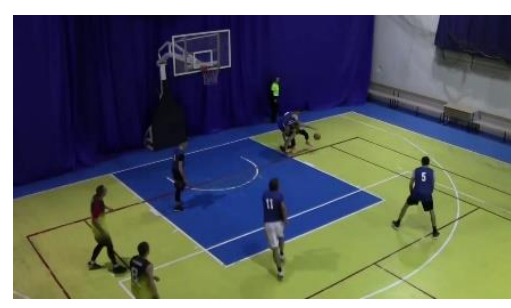

2

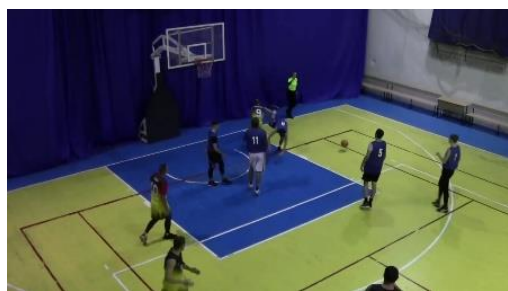

3

Fig. 3. Illustrations for Test №1

Test No. 2 (Fig. 4). Who is fouled and why? uniform

A) Foul (normal) against player \# 23 in black

B) Player \# 4 offensive foul (yellow kit) (black kit)

C) Unsportsmanlike foul against player \# 23

D) Public foul against player \# 4 (yellow kit) and player \# 23 (black kit) 


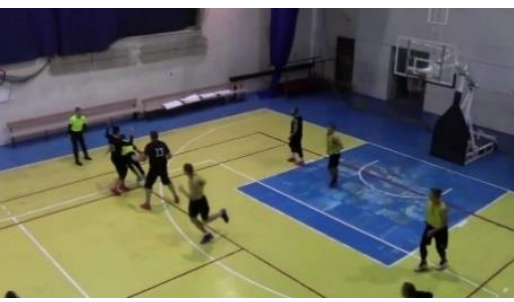

1

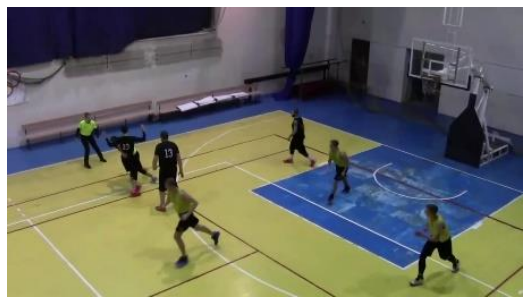

2

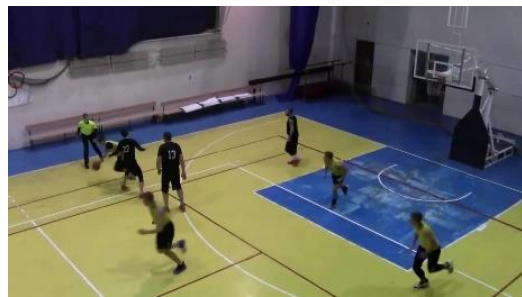

3

Fig. 4. Illustrations for Test №2

Test number 3. Who is fouled and why? Count the scored 3 points? 3 points

A) Foul against player \# 13 (white kit), count

B) Foul (normal) against player \# 3 in black uniform, count 3 points.

C) Foul (normal) against player \# 3 in black uniform, not counting 3 points.

D) Foul (normal) against player \# 13 in white uniform, not counting 3 points.

E) Offensive foul against player \# 3 in black uniform, not counting 3 points.

Answer: C

Section 6. Technical readiness "Referee' gestures"

This section contains illustrations of all the referee's gestures with a detailed description.

\section{Results}

At the beginning of the experiment, the control and experimental groups did not significantly differ from each other in all testing indicators $(\mathrm{p}>$ 0.05) (Table 3).

Table 3

The results of testing the comprehensive preparation of basketball referees of the experimental $(n=15)$ and control $(n=15)$ groups for the experiment

\begin{tabular}{|c|c|c|c|c|c|}
\hline \multirow{2}{*}{ Name of metrics } & \multirow{2}{*}{ Group } & \multicolumn{4}{|c|}{ Statistical Indicators } \\
\hline & & $\bar{x}$ & $\mathrm{~S}$ & $\mathrm{t}$ & $p$ \\
\hline \multirow{2}{*}{ Jumping rope in 1 minute, number of times } & $E$ & 118,14 & 4,13 & \multirow{2}{*}{1,75} & \multirow{2}{*}{0.14} \\
\hline & $\mathrm{C}$ & 120,43 & 2,59 & & \\
\hline \multirow{2}{*}{$\begin{array}{l}\text { Stretch of the upper-body forward from a } \\
\text { sitting position, sm }\end{array}$} & $\mathrm{E}$ & 10,36 & 2,27 & \multirow{2}{*}{$-1,67$} & \multirow{2}{*}{0.17} \\
\hline & $\mathrm{C}$ & 11,59 & 1,03 & & \\
\hline \multirow{2}{*}{ Push-ups $30 \mathrm{~s}$, number of times } & $E$ & 49,2 & 8,48 & \multirow{2}{*}{0,28} & \multirow{2}{*}{0.80} \\
\hline & C & 48,5 & 7,65 & & \\
\hline \multirow{2}{*}{ Pulling up on the bar, number of times } & $E$ & 13,2 & 3,2 & \multirow{2}{*}{0,88} & \multirow{2}{*}{0.45} \\
\hline & C & 12,25 & 3,87 & & \\
\hline \multirow{2}{*}{ Long jump from a place, sm } & $\mathrm{E}$ & 194,93 & 2,40 & \multirow{2}{*}{$-1,32$} & \multirow{2}{*}{0.27} \\
\hline & $\mathrm{C}$ & 196,64 & 3,32 & & \\
\hline \multirow{2}{*}{ Running $3000 \mathrm{~m}$, min } & $\mathrm{E}$ & 13,24 & 3,61 & \multirow{2}{*}{$-0,09$} & \multirow{2}{*}{0.94} \\
\hline & $\mathrm{C}$ & 13,35 & 3,86 & & \\
\hline \multirow{2}{*}{ Romberg's test, s } & $E$ & 39,53 & 2,98 & \multirow{2}{*}{1,38} & \multirow{2}{*}{0.23} \\
\hline & C & 38,07 & 2,77 & & \\
\hline \multirow{2}{*}{$\begin{array}{l}\text { Lifting the trunk in sitting position for } 1 \mathrm{~min} \text {, } \\
\text { number of times }\end{array}$} & $\mathrm{E}$ & 51,03 & 7,68 & \multirow{2}{*}{$-0,91$} & \multirow{2}{*}{0.52} \\
\hline & $\mathrm{C}$ & 53,18 & 7,81 & & \\
\hline \multirow{2}{*}{ Genchi's test, s } & $\mathrm{E}$ & 39,50 & 3,12 & \multirow{2}{*}{$-1,34$} & \multirow{2}{*}{0.31} \\
\hline & C & 41,00 & 2,98 & & \\
\hline Stanog'ctect c & $\mathrm{E}$ & 41,7 & 2,31 & & 035 \\
\hline Stange's test, s & C & 42,6 & 2,43 & 1,03 & 0.35 \\
\hline & $\mathrm{E}$ & 6,75 & 2,14 & & \\
\hline Rufier's test, conventional units & $\mathrm{C}$ & 5,16 & 2,02 & 2,01 & 0.09 \\
\hline "Simple visual-motor reaction" is the time of & $\mathrm{E}$ & 302,25 & 71,43 & 064 & 056 \\
\hline the latent period., ms & $\mathrm{C}$ & 286,45 & 62,65 & 0,64 & 0.56 \\
\hline "Simple visual-motor reaction" errors, & $\mathrm{E}$ & 3,72 & 0,79 & 061 & 054 \\
\hline number & $\mathrm{C}$ & 3,91 & 0,82 & 0,61 & 0.54 \\
\hline "Reaction of choice $2-3$ " time of latent period, & $\mathrm{E}$ & 503,78 & 123,67 & 010 & 071 \\
\hline $\mathrm{ms}$ & $\mathrm{C}$ & 499,11 & 121,9 & 0,10 & 0.11 \\
\hline "Reaction of choice 2-3" & $\mathrm{E}$ & 21,92 & 5,98 & 1,19 & 026 \\
\hline ction of choice 2 & $\mathrm{C}$ & 19,07 & 4,34 & 1,49 & 0.26 \\
\hline
\end{tabular}


After the experiment, the referee of the experimental group showed a significant improvement in the test results "jumping rope for 1 min, the number of times", "Romberg's test, s" (p
$<0.05)$. Improvement of coordination qualities determines the speed of mastering new motor forms, can positively affect the efficiency and productivity of basketball referee' actions (Table 4).

Table 4

The results of testing the comprehensive preparation of basketball referees of the experimental $(n=15)$ and control $(n=15)$ groups after the experiment

\begin{tabular}{|c|c|c|c|c|c|}
\hline \multirow{2}{*}{ Name of metrics } & \multirow{2}{*}{ Group } & \multicolumn{4}{|c|}{ Statistical Indicators } \\
\hline & & & $\mathrm{S}$ & $\mathrm{t}$ & $p$ \\
\hline \multirow{2}{*}{ Jumping rope in 1 minute, number of times } & $E$ & 123,2 & 3,35 & \multirow{2}{*}{2,56} & \multirow{2}{*}{0.02} \\
\hline & $\mathrm{C}$ & 119,9 & 3,68 & & \\
\hline \multirow{2}{*}{$\begin{array}{l}\text { Stretch of the upper-body forward from a sitting } \\
\text { position, sm }\end{array}$} & $\mathrm{E}$ & 10,64 & 1,69 & \multirow{2}{*}{0,36} & \multirow{2}{*}{0.45} \\
\hline & C & 10,86 & 1,96 & & \\
\hline \multirow{2}{*}{ Push-ups $30 \mathrm{~s}$, number of times } & $\mathrm{E}$ & 56,2 & 6,48 & \multirow{2}{*}{$-0,65$} & \multirow{2}{*}{0.61} \\
\hline & C & 57,5 & 6,65 & & \\
\hline \multirow{2}{*}{ Pulling up on the bar, number of times } & $\mathrm{E}$ & 18,01 & 2,59 & \multirow{2}{*}{2,41} & \multirow{2}{*}{0.03} \\
\hline & C & 15,88 & 2,23 & & \\
\hline \multirow{2}{*}{ Long jump from a place, sm } & $\mathrm{E}$ & 198,93 & 2,23 & \multirow{2}{*}{2,12} & \multirow{2}{*}{0.02} \\
\hline & C & 200,64 & 2,17 & & \\
\hline \multirow{2}{*}{ Running $3000 \mathrm{~m}$, min } & $E$ & 12,43 & 1,02 & \multirow{2}{*}{1,01} & \multirow{2}{*}{0.13} \\
\hline & C & 12,88 & 1,1 & & \\
\hline \multirow{2}{*}{ Romberg's test, s } & $\mathrm{E}$ & 43,18 & 3,14 & \multirow{2}{*}{2,48} & \multirow{2}{*}{0.05} \\
\hline & $\mathrm{C}$ & 40,07 & 3,68 & & \\
\hline \multirow{2}{*}{$\begin{array}{l}\text { Lifting the trunk in sitting position for } 1 \mathrm{~min} \text {, } \\
\text { number of times }\end{array}$} & $\mathrm{E}$ & 57,06 & 7,43 & \multirow{2}{*}{$-0,48$} & \multirow{2}{*}{0.65} \\
\hline & $\mathrm{C}$ & 58,18 & 7,74 & & \\
\hline \multirow{2}{*}{ Genchi's test, s } & $E$ & 41,43 & 2,86 & \multirow{2}{*}{$-1,18$} & \multirow{2}{*}{0.15} \\
\hline & $\mathrm{C}$ & 42,54 & 2,23 & & \\
\hline Stange's test s & $E$ & 45,8 & 3,54 & -132 & 013 \\
\hline Stange s test, $\mathrm{s}$ & $\mathrm{C}$ & 47,6 & 3,87 & $-1,3<$ & 0.13 \\
\hline Rufier's test conventional units & $E$ & 3,96 & 1,68 & -298 & 0.04 \\
\hline 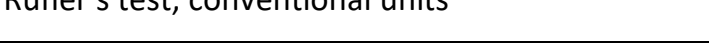 & $\mathrm{C}$ & 5,62 & 1,35 & $-2, \mathrm{JO}$ & 0.04 \\
\hline "Simple visual-motor reaction" is the time of the & $\mathrm{E}$ & 251,12 & 51,98 & & \\
\hline latent period., ms & C & 295,6 & 55,23 & 2,21 & 0.03 \\
\hline "Simple visual-motor reaction" errors, & $\mathrm{E}$ & 1,61 & 0,44 & & \\
\hline number & C & 1,45 & 0,51 & 0,91 & 0.52 \\
\hline "Reaction of choice 2-3" time of latent neriod ms & $\mathrm{E}$ & 484,23 & 112,34 & O 32 & 043 \\
\hline keaction or cnoice z-s lime or ratent perrod, ms & $\mathrm{C}$ & 471,34 & 105,67 & 0,32 & 0.45 \\
\hline & $\mathrm{E}$ & 14,58 & 3,56 & & \\
\hline "Reaction of choice $2-3$ ", errors, number & $\mathrm{C}$ & 15,33 & 4,12 & 0,53 & 0.24 \\
\hline
\end{tabular}

Notes: ${ }^{*} \mathrm{E}-$ experimental group; $\mathrm{C}$ - control group

Also, significant differences were revealed in the indicators "pulling up on the bar, the number of times", "running $3000 \mathrm{~m}$, min", the experimental group compared with the referee of the control group ( $p$ <0.05). After the experiment, significant differences $(\mathrm{p}<0.05)$ were found between the control and experimental groups in the "Rufier test".
In the control group, significant differences were found in the test "long jump from the spot, $\mathrm{cm}$ " in comparison with the experimental one $(p<0.05)$. As a result of the method of expert evaluations, significant $(p<0.05)$ differences were revealed in the indicators of the tests "technique of gestures", "mechanics of double refereeing" in the experimental group in comparison with the referee of the control group (table. 5). 
The results of testing the technical readiness of referee of the experimental $(n=15)$, control $(n=15)$ groups before and after the experiment

\begin{tabular}{|c|c|c|c|c|c|c|c|c|c|c|c|c|}
\hline \multirow{3}{*}{ Tests } & \multicolumn{6}{|c|}{ Control group } & \multicolumn{6}{|c|}{ Experimental group } \\
\hline & \multicolumn{2}{|c|}{$\begin{array}{l}\text { to the } \\
\text { experiment }\end{array}$} & \multicolumn{2}{|c|}{$\begin{array}{c}\text { after the } \\
\text { experiment }\end{array}$} & \multirow[t]{2}{*}{$\mathrm{t}$} & \multirow{2}{*}{$p$} & \multicolumn{2}{|c|}{$\begin{array}{c}\text { to the } \\
\text { experiment }\end{array}$} & \multicolumn{2}{|c|}{$\begin{array}{c}\text { after the } \\
\text { experiment }\end{array}$} & \multirow[t]{2}{*}{$\mathrm{t}$} & \multirow{2}{*}{$\mathrm{p}$} \\
\hline & $\bar{x}$ & $\mathrm{~s}$ & $\bar{x}$ & $\mathrm{~s}$ & & & $\bar{x}$ & $\mathrm{~s}$ & $\bar{x}$ & $\mathrm{~s}$ & & \\
\hline $\begin{array}{l}\text { Technique for } \\
\text { performing } \\
\text { gestures, } \\
\text { conventional } \\
\text { units }\end{array}$ & 3,89 & 0,83 & 4,01 & 0,81 & 0,40 & 0.34 & 3,70 & 0,97 & 4,34 & 0,15 & 2,52 & 0,01 \\
\hline $\begin{array}{l}\text { Double judging } \\
\text { mechanics, } \\
\text { conventional } \\
\text { units }\end{array}$ & 3,10 & 1,98 & 3,96 & 1,62 & 1,30 & 0.13 & 3,06 & 1,64 & 4,13 & 0,89 & 2,22 & 0.02 \\
\hline
\end{tabular}

\section{Discussion}

In sports science, little attention is paid to the methodology of training referees compared to the training of athletes and coaches. The lack of a clear system of selection and refereeing training led to a noticeable lag in the professional skill of referees from the level of basketball development [13-15].

In this study, a hypothesis was put forward that the use of video manuals in the preparation of young referees will improve their physical and technical readiness in the conditions of refereeing. This hypothesis was fully confirmed. The results obtained agree with the studies that the degree of general preparedness of the arbiters is determined by the level of physical fitness, the level of theoretical training, the level of psychological training, the level of practical training, personal characteristics (type of temperament) [16-18]. The research showed that the results of testing physical and functional readiness among the referees of the experimental group increased. This can be explained by the fact that the complexes of exercises for improving all types of readiness provided in the video manual can effectively increase the level of sports training of referees of this category. In this electronic learning tool, combined educational information that allows you to get a set of knowledge and skills on basketball refereeing, as well as practical information that allows you to control the complex readiness necessary for a category $\mathrm{C}$ referee.

In basketball referee training, refereeing mechanics plays a major role - a system designed as a practical method that facilitates the duties of referees on the court. It is designed to help them take the best place, which allows them to make the right decision when the rules are violated. Refereeing technique including clear communication and consistency of referees, with one referee responsible for overseeing play around the ball and the other for off-ball play. In order to achieve the best observation, officials should try to take the most advantageous positions for judging game action using the judging mechanics.

The data obtained indicate an improvement in the technique and mechanics of refereeing the referees in the experimental group. This can be explained by the fact that the formation of a technical skill becomes more effective with a detailed study of techniques and repeated repetition of technical actions. The effectiveness of the assimilation of the material increases with the dynamism of the presentation of information. The dynamism allows you to provide the intensity of the presentation of information, which is necessary in the learning process. In the theoretical section of the manual there are tests with video files, after watching which the referees must choose the correct answer. Viewing and solving such game moments allows you to form the correct interpretation of violations and improve gestures.

Arbitrators of this age category need active development of professional mental qualities, namely, the accuracy of perception of short time intervals $(3 \mathrm{~s}, 5 \mathrm{~s}, 10 \mathrm{~s})$ and the organization of attention. The situation during the game forces the referees to react with maximum speed and accuracy, the timeliness and correctness of the interpretation of the game moments depends on the set of psychophysiological mechanisms that perceive, process, store and transmit information about the game actions[19-20]. The presence of the built-in program "Psychodiagnostics" in the video manual will allow you to control the level of psychophysiological capabilities of the arbitrators. 
The presented exercises for the development of a sense of time, reaction speed, thinking efficiency will help to improve psychophysiological abilities, which will increase the quality of practical refereeing, the ability to control the game, and help control time.

\section{Conclusions}

A video manual "Challenge for Referees" has been developed with the help of which it is possible to determine the level of physical, functional and technical readiness of young basketball referees, their psychophysiological capabilities for providing practical recommendations in preparation for the playing season. Revealed significant differences in the indicators "pulling up on the bar", "running 3000 $\mathrm{m}$ ", "Rufier's test" of the experimental group in comparison with the referees of the control group ( $p$ $<0.05)$ as a result of the use of the video manual "Challenge for Referees" in preparation for the game season. In the control group, significant differences were found in the test "long jump from a spot" in comparison with the experimental group $(p<0.05)$.

\section{Acknowledgments}

The study was conducted according to: research work, which is funded by the state budget of the Ministry of Education and Science of Ukraine for 2019-2020. " Theoretical and methodological foundations for the use of integral technologies for self-improvement, harmonious physical, intellectual and spiritual development and the formation of a healthy lifestyle for people of different age and social groups, including athletes and people with special needs (State Registration No: 0119U100616).

\section{Conflict of interest}

The authors declare that there is no conflict of interest.

\section{References}

1. Koneva EV. Improvement of the basketball referee training system. In: actual problems and modern technologies: materials of the All-Russian scientificpractical conference with international participation. FSBEI HPE "RGUFKSMT", 2013;75-79. (In Russian)

2. Iglesias DS, Leicht AS, Pojskic H, Vaquera A. Impact of contextual factors on match demands experienced by elite male referees during international basketball tournaments. Journal of sports sciences, 2020, DOI: 10.1080/02640414.2020.1851902

3. Sobko IM, Duhinova HS, Zolotukhin OO. Features of the integrated training of young basketball referees before the game season. Sportyvni ihry. 2020;1(15):34-44 doi: 10.15391/si.2020-1.04. (In Ukrainian)

4. Garcia-Santos D, Ibanez SJ. Design and validation of an observational instrument to basketball referee evaluation (IOVAB). Sport tk-revista euroamericana de ciencias del deporte, 2016;5(2):15-26.

5. Morgulev E, Azar O, Lidor R. Searching for Judgment Biases Among Elite Basketball Referees. Frontiers in psychology, 2018; 9:2665-2673.

6. Nabli MA, Abdelkrim NB, Fessi MS. Sport science applied to basketball refereeing: a narrative review. Physician and sports medicine, 2019;13(1):675-679.

7. Arbinaga Fernandez-Ozcorta JE, Herrera-Macias P. Burnout syndrome and resilience in soccer and basketball referees. Revista de psicologia del deporte, 2019;28(2):23-32.

8. Pecev P, Rackovic M, Ivkovic M. A system for deductive prediction and analysis of movement of basketball referees. Multimedia tools and applications, 2016;75(23):16389-16416.

9. Sors F, Lourido D, Parisi V. Pressing crowd noise impairs the ability of anxious basketball referees to discriminate fouls. Frontiers in psychology, 2019;10:2380-2386.

10. Pratama R, Januarto OB. Video Based Learning for Basketball Referee. Proceedings of the 2nd international conference on sports sciences and health, 2018; 7:10-16.

11. Kozina Z, Iermakov S, Bartík P, Yermakova T, Michal J. Influence of self-regulation psychological and physical means on aged people's functional state. Journal of Human Sport and Exercise, 2018; 13(1):99115. doi:https://doi.org/10.14198/jhse.2018.131.10

12. Dmitriev FB. Comprehensive training methodology and performance criteria for basketball referees: Monograph, Moscow: Nauka Publishing Center, 2017, 128. (In Russian)

13. Almeida FR, da Silva CB, Vendramini CMM, de Campos C, Brandao MRF. Psychometric properties of the brazilian version of the brums scale for basketball referees. Revista de psicologia del deporte, 2018;27:37-44

14. Kozina ZhL, Sobko IM, Vilvitskii VO, Xiaofei Wang, S.V. Borovskii, Tymko YN, Glyadya SA, Minak AF. Method of integral development of speed-power qualities and accuracy of throws at young basketball players 12-13 years. Health, sport, rehabilitation, 2018; 4(2): 39-51. doi:10.34142/HSR.2018.04.02.04 (In Ukrainian)

15. Lakhno O G, Shyyan O V, Shyyan VM, Solohubova $\mathrm{SV}$, Sherman OA. Use of elements of basketball as a 
means of psychomotor development of students. Health, sport, rehabilitation, 2020; 6(1): 32-40. doi:10.34142/HSR.2020.06.01.04

16. Pomeshchikova IP, Chucha NI, Chucha YI, Kudimova $\mathrm{OV}$. Changes in coordination abilities at basketball players of the student's team under the influence of specially selected exercises with balls. Sportyvni ihry. 2020; 020№2(16):58-66. doi: 10.15391/si.2020-2.06. (In Ukrainian)

17. Leicht AF, Connor JI. External Activity Demands Differ Between Referees and Players During a SubElite, Men's Basketball Match. Research quarterly for exercise and sport, 2019;90(4):720-725.
18. Garcia-Santos D, Pino-Ortega J, Garcia-Rubio J. Internal and External Demands in Basketball Referees during the U-16 European Women's Championship. International journal of environmental research and public health, 2019;16(18):3421.

19. Garcia-Santos D, Vaquera A, Calleja-Gonzalez J. Stress and technique of basketball refereeing according to gender. Revista de psicologia del deporte, 2018;89(1):142-143.

20. Leicht S. Fox J, Connor J. External Activity Demands Differ Between Referees and Players During a SubElite, Men's Basketball Match. Research quarterly for exercise and sport, 2019;90(4):720-725.

\section{Information about the authors}

\section{Sobko I.N.}

http://orcid.org/0000-0001-5588-4825

sobko.iryna18@gmail.com

H. S. Skovoroda Kharkiv National Pedagogical University

Alchevskikh st. 29, Kharkiv, 61002, Ukraine

\section{Chucha Y.I.}

https://orcid.org/0000-0002-7563-6359

chychayi@ukr.net

Kharkiv State Academy of Physical Culture: Klochkivska

str. 99, Kharkiv, 61058, Ukraine

\section{Podmaryova I.A.}

https://orcid.org/0000-0002-9339-6504

podmareva@ukr.net

S. Kuznets Kharkiv National University of Economics;

Nauki Ave. 9A, Kharkov, 61166, Ukraine

\section{Nagovitsyna O.P.}

https://orcid.org/0000-0002-5170-8231

olga.nagovicina5@gmail.com

S. Kuznets Kharkiv National University of Economics;

Nauki Ave. 9A, Kharkov, 61166, Ukraine

\section{Zhuravlova I.M.}

https://orcid.org/0000-0001-5927-4856

irinazhuravlyova.ukr@gmail.com

Municipal establishment "Kharkiv humanitarian-pedagogical academy" of the Kharkiv regional council Rustaveli lane, 7, Kharkov, Ukraine

\section{Інформація про авторів}

\section{Собко I.M.}

http://orcid.org/0000-0002-4920-9775

sobko.iryna18@gmail.com

Харківський національний педагогічний університет імені Г.С. Сковороди, вул. Алчевських 29, Харків, 61002, Україна 


\section{Чуча Ю.I.}

https://orcid.org/0000-0002-7563-6359

chychayi@ukr.net

Харківська державна академія фізичної культури

вул. Клочківська, 99, Харків, 61058, Україна

\section{Подмарьова I.A.}

https://orcid.org/0000-0002-9339-6504

podmareva@ukr.net

Харківський національний економічний університет ім. С. Кузнеця,

пр. Науки 9А, р .. Харків, 61166, Україна;

\section{Наговіцина О.П.}

https://orcid.org/0000-0002-5170-8231

olga.nagovicina5@gmail.com

Харківський національний економічний університет ім. С. Кузнеця, пр. Науки 9А, р .. Харків, 61166, Україна;

\section{Журавльова I.M.}

https://orcid.org/0000-0001-5927-4856

irinazhuravlyova.ukr@gmail.com

Комунальний заклад «Харківська гуманітарно-педагогічна академія» Харківської обласної ради пров. Руставелі, 7, м. Харків, Україна

\section{Информация об авторах}

\section{Собко И.Н.}

http://orcid.org/0000-0002-4920-9775

sobko.iryna18@gmail.com

Харьковский национальный педагогический университет имени Г.С. Сковороды, ул. Алчевских 29, Харьков, 61002, Украина

\section{Чуча Ю.И.}

https://orcid.org/0000-0002-7563-6359

chychayi@ukr.net

Харьковская государственная академия физической культуры ул. Клочковская, 99, Харьков, 61058, Украина

\section{Подмарева И.А.}

https://orcid.org/0000-0002-9339-6504

podmareva@ukr.net

Харьковский национальный экономический университет им. С. Кузнеца, пр. Науки 9А, г.. Харьков, 61166, Украина;

\section{Наговицина О.П.}

https://orcid.org/0000-0002-5170-8231

olga.nagovicina5@gmail.com

Харьковский национальный экономический университет им. С. Кузнеца, пр. Науки 9А, г.. Харьков, 61166, Украина;

\section{Журавлева И.Н.}

https://orcid.org/0000-0001-5927-4856

irinazhuravlyova.ukr@gmail.com

Коммунальное учреждение «Харьковская гуманитарно-педагогическая академия» Харьковского областного совета

пер. Руставели, 7, г.. Харьков, Украина

This work is licensed under a Creative Commons Attribution 4.0 International License (CC BY 4.0) 